\title{
Virtual museum tour in Wasaka Banjarmasin to introduce the collection of leaders and local heroes based on mobile augmented reality technology in the new normal era
}

\author{
Aulia Akhrian Syahidi ${ }^{1, *}$, Subandi ${ }^{2}$, Adistya Nadia Azura ${ }^{3}$, Ida Hastuti ${ }^{4}$ \\ ${ }^{1,3}$ Interactive Media, Game, and Mobile Technologies Research Group, \\ Augmented Reality and Virtual Reality Laboratory, Politeknik Negeri Banjarmasin, Indonesia \\ ${ }^{2}$ Smart City Information System Study Program, Politeknik Negeri Banjarmasin, Indonesia \\ ${ }^{4}$ Informatics Engineering Study Program, Politeknik Negeri Banjarmasin, Indonesia
}

\begin{tabular}{l}
\hline Article Info \\
\hline Article history: \\
Received December 6, 2020 \\
Accepted December 23, 2020 \\
Published May 1, 2021 \\
\hline
\end{tabular}

\section{Keywords:}

Extreme Programming Mobile Augmented Reality

Tourism Application

Virtual Museum Tour

\begin{abstract}
Wasaka Museum is one of the museums in Banjarmasin City. However, the information obtained by visitors at this time is only from short writings near the object of the image, and museum guards cannot accompany visitors to get around. Furthermore, the interest of museum visitors has also decreased due to the unavailability of adequate information, minimal services, and the impact of the COVID-19 pandemic. The purpose of this research is to develop applications using Mobile Augmented Reality Technology as a means of promotion, trying to attract visitors with AR interaction treats, and the form of virtual museum tours. The methodology used is the Agile Development Method with the type of Extreme Programming (XP). Then the A/B Testing Method is used to select the user interface design. Marker-Based Tracking is a method of detecting markers so that $3 \mathrm{D}$ objects can appear. The conclusion is that the selected interface design is design B with a percentage of $76.9 \%$, all the features in the application have functioned very well, and the results of the usability evaluation with a percentage of $83.33 \%$ have an Excellent predicate which means that they can be recommended for further use at the Wasaka Museum Banjarmasin in the New Normal Era.
\end{abstract}

\section{Corresponding Author:}

Aulia Akhrian Syahidi,

Interactive Media, Game, and Mobile Technologies Research Group,

Augmented Reality and Virtual Reality Laboratory, Politeknik Negeri Banjarmasin,

Brigjend H. Hasan Basri Road, Kayutangi, Banjarmasin City, South Kalimantan, Indonesia

Email: *aakhriansyahidi@poliban.ac.id

\section{INTRODUCTION}

One of the museums in the city of Banjarmasin is the Wasaka Museum (Waja Sampai Ka Puting). Inaugurated on November 10, 1991, it is a museum of the struggle of the people of South Kalimantan against the Dutch colonial government. In general, the collections contained in the museum are photos of national leaders/figures, maps and battle weapons, headquarters equipment, battle clothes, and other supporting equipment.

However, the information obtained by visitors at this time is only from short writing near the image/object (not to mention that there is damaged writing), the museum guard cannot accompany the visitor around to explain further about the leader/figure in the picture/existing objects so that visitors find it difficult to get more and more detailed information from the collections available at the Wasaka Museum. As a result of the difficulty in obtaining this information, the public's interest in visiting this museum has decreased, coupled with the occurrence of the COVID-19 pandemic, so that the impact of the decrease in visitors will be felt even more.

Several museums in Indonesia have also experienced a decrease in the number of visitors, but before the COVID-19 pandemic, one of them is the West Kalimantan Museum [1], the Bali Museum [2], the Batara Guru Museum [3], and several other museums. Seeing these conditions, so we need a technology-assisted 
innovation in the form of applications that can attract public interest, one of which is recommending applications based on Mobile Augmented Reality.

According to [4] states that Augmented Reality (AR) is a technology that overlays virtual objects and information or [5] merging or overlapping virtual objects into the real world. Furthermore, [6] explained that $\mathrm{AR}$ is the integration of digital information with the real world in real-time, where this technology requires markers to generate $3 \mathrm{D}$ objects as a result of the detection of marker patterns assisted by programmed AR cameras. AR cameras can be in the form of cameras on computers (webcam), android smartphones, and special glasses such as google glass/smart glasses. AR can provide magical elements [7], very rich interactions, and supports a very good user experience [8].

Mobile Augmented Reality can be defined as an AR application that can only be installed and used on a mobile/smartphone device [9]. The urgency of the proposed research is to develop a virtual museum tourism application based on Mobile Augmented Reality technology in the collection room for the introduction of local leaders/figures and heroes at the Wasaka Museum in Banjarmasin, as a means to attract visitors in the new normal era and still prioritize health protocols. With AR, visitors do not need to touch objects in the museum, just install the application and point it at the object.

\section{RESEARCH METHOD}

Extreme Programming (XP) software development method is used as a method in this research. XP is the most widely used agile process [10]. According to [8] states that XP is a methodology that has four performance phases, namely planning, design, coding, and testing (See Figure 1).

In today's era XP is quite widely used, XP is one type of Agile Methods which has become a very well-known software development approach, especially for the development of mobile applications and mobile games with a relatively small number of programmers, and also demands agile action in it copes with the many changes in its development and to meet user needs quickly.

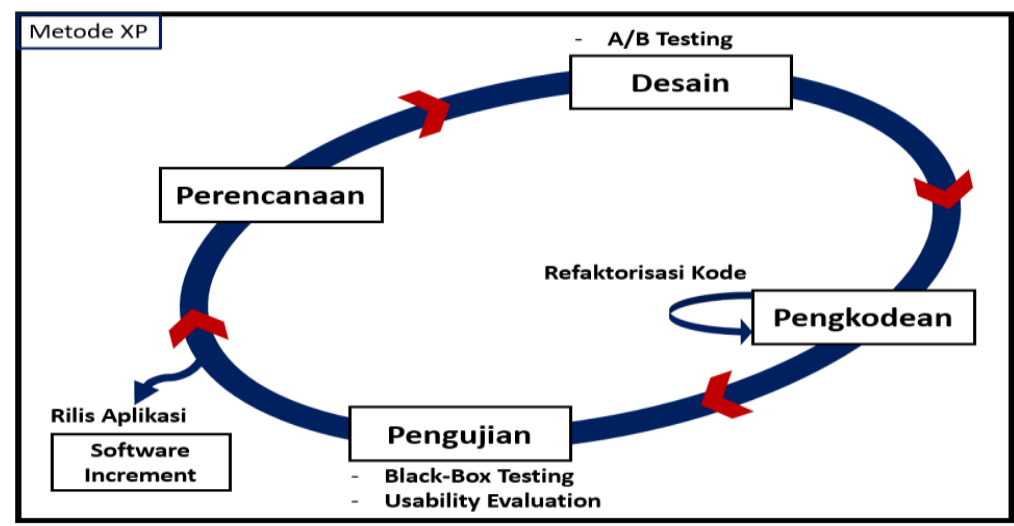

Figure 1. XP Development Method

Based on Figure 1, which adapts from [10] for the XP stage in detail, namely (1) the activity planning stage is to collect information and requirements analysis; (2) The design stage is highly recommended to use a simple type of design because it tends to be preferred; (3) The coding stage is creating an application architecture (building applications based on the results of design selection) through the coding process; and (4) The testing phase where the application will be tested so that it can be seen whether the application can function as expected or there is still a function that is failing/inappropriate.

Then outside of the main XP performance stages, there are several activities to support the main performance stages, namely (1) Refactoring is one of the most important aspects of XP, which has a function to make changes to the program code of the software, aiming to improve the quality of the program structure without changing the way the program works; (2) Application release (small release), which is every software developer completes a unit or part of the software, then these results must be immediately presented and discussed with the client, even though the software has not been completed or there are still errors/bugs, but it must be recommended for release so that the software can be used quickly; and (3) Software increments, namely the stages to evaluate all kinds of deficiencies of the software and fix them as a way to nimbly meet user needs.

Furthermore, at the design stage, it is necessary to test candidates from the user interface design using the A/B Testing method. According to [11] states that the A/B Testing method is a testing phase to compare two (or more) versions of the user interface page that is owned to determine which design is recommended and can work better in supporting a suitable user interface and supporting the simple design (in line with the XP concept of not liking complicated designs in software development). 
In AR technology, there are two methods to detect targets in the form of markers that are used to generate 3D objects as a result of detection, namely the Marker-Based Tracking and Markerless Tracking Methods. In this study, the Marker-Based Tracking Method was applied [7], namely AR technology which requires special markers to be made such as barcodes or black frames, QR codes, and printed markers that have a certain pattern to be detected by a computer via a connected camera or a smartphone programmed.

In the test performance, the Black-Box Testing Method is used, according to [12] states that this test is carried out to test the functionality of the software that has been developed, by checking the functioning of the units/parts of each feature in the software.

The Usability Evaluation Method is used non-functionally. According to [13] it is a way to improve and find out how feasible the software is to be implemented based on the aspects of ease of learning, ease of use, and attracting users to reuse it. In its application, it uses the System Usability Scale (SUS) which was adapted from [14], a questionnaire that aims to measure perceptions of usability using a Likert scale rating from 1-5 (positive statement scores) by assessing how many users agree with the ten test statement features provided. After obtaining the final average result of the SUS value, it will be interpreted (See Table 1).

Table 1. Reference to SUS Final Score Interpretation

\begin{tabular}{ccc}
\hline SUS Score & Interpretation & Predicate \\
\hline$>80,3$ & A & Excellent \\
$69-80,3$ & B & Good \\
68 & C & Above Average \\
$51-67$ & D & Below Average \\
$<51$ & E & Bad \\
\hline
\end{tabular}

Based on Table 1, the minimum final value of SUS with the standard average is 68 in the Above Average category. If the final result of the SUS score for software or features is below that value, it is recommended to work even harder in making improvements and improving the usability of the software or features that have been proposed.

\section{RESULTS AND ANALYSIS}

\subsection{Planning}

The planning stages carried out include (1) data collection consisting of observation by observing the conditions and problems that occur and documenting them; (2) the literature study is conducted to find similar research and other related sources as research support; and (3) requirements analysis includes activities in determining requirements or conditions that must be met by the application/software to be created, consisting of functional requirements (See Table 2) and non-functional requirements (See Table 3).

Table 2. Functional Requirements

\begin{tabular}{clc}
\hline Id & \multicolumn{1}{c}{ Description } & Priority \\
\hline AR-WasakaF01 & $\begin{array}{l}\text { After the user accesses the AR-Wasaka application .apk, then the user } \\
\text { before entering the main menu page will be presented with a splash screen } \\
\text { for three seconds. }\end{array}$ & Must \\
AR-WasakaF02 & Users can access the main menu page. & Must \\
AR-WasakaF03 & Users can access the start button and enter the camera AR page. & Must \\
AR-WasakaF04 & $\begin{array}{l}\text { Users can access the hint button and open a page that contains instructions } \\
\text { for using the AR-Wasaka application. }\end{array}$ & Must \\
AR-WasakaF05 & $\begin{array}{l}\text { Users can access the information button and open a page that contains AR- } \\
\text { Wasaka application developer information. }\end{array}$ & Must \\
AR-WasakaF06 & Users can access the exit button so that they can fully exit the AR-Wasaka & Must
\end{tabular}


application.

AR-WasakaF07 Users can access the back button when on a certain page to be redirected

Must back to the main menu page.

AR-WasakaF08 Users can access the barcode marker detection camera and generate 3D

Must objects.

AR-WasakaF09 Users can access audio as information from the 3D object leaders/figures and local heroes of Banjarmasin.

Based on Table 2, it is the functional requirements of the AR-Wasaka application that will be made, consisting of nine functional requirements that must be met (priority must) as a reference for manufacture and function. This effort is an effort so that the success rate of application/software development can be achieved properly.

Table 3. Non-Functional Requirements

\begin{tabular}{|c|c|c|}
\hline Id & Description & Priority \\
\hline AR-WasakaNF01 & $\begin{array}{l}\text { (Availability) - The availability of the AR-Wasaka application to be } \\
\text { accessible by users. }\end{array}$ & Must \\
\hline AR-WasakaNF02 & $\begin{array}{l}\text { (Reliability) - The reliability of the AR-Wasaka application when installed } \\
\text { on a smartphone device and without using an internet connection. }\end{array}$ & Must \\
\hline AR-WasakaNF03 & $\begin{array}{l}\text { (Ergonomy) - The user interface design of the AR-Wasaka application can } \\
\text { be adjusted according to user convenience. }\end{array}$ & Must \\
\hline AR-WasakaNF04 & $\begin{array}{l}\text { (Portability) - The move/technique of adapting the AR-Wasaka } \\
\text { application, so that it can be accessed by various devices that are relevant } \\
\text { to the .apk file extension. }\end{array}$ & Must \\
\hline AR-WasakaNF05 & $\begin{array}{l}\text { (Memory) - The need for the AR-Wasaka application for the storage } \\
\text { media on the device. }\end{array}$ & Must \\
\hline AR-WasakaNF06 & $\begin{array}{l}\text { (Response time) - The response time of the AR-Wasaka application to all } \\
\text { requests from users. }\end{array}$ & Must \\
\hline AR-WasakaNF07 & $\begin{array}{l}\text { (Safety) - The AR-Wasaka application can guarantee the safety of data } \\
\text { and its use. }\end{array}$ & Must \\
\hline AR-WasakaNF08 & $\begin{array}{l}\text { (Programming language) - The programming language used to build AR- } \\
\text { Wasaka applications is C\# (Unity 3D), in collaboration with supporting } \\
\text { software such as Blender and Vuforia SDK. }\end{array}$ & Must \\
\hline
\end{tabular}

Based on Table 3, it is a non-functional requirement that focuses on the properties of the behavior and service limitations of the application/software, consisting of eight needs that must be met (priority must).

\subsection{Design}

Design is a continuation of the planning stages, especially in the results of the needs analysis. The design in this study consisted of:

\section{Activity Diagram}

The activity diagram design is used to determine the activity flow of the AR-Wasaka application that will be run. In the activity diagram (See Figure 2), the steps are made very detailed, what actions are performed by the user, will cause a reaction from the application itself. 


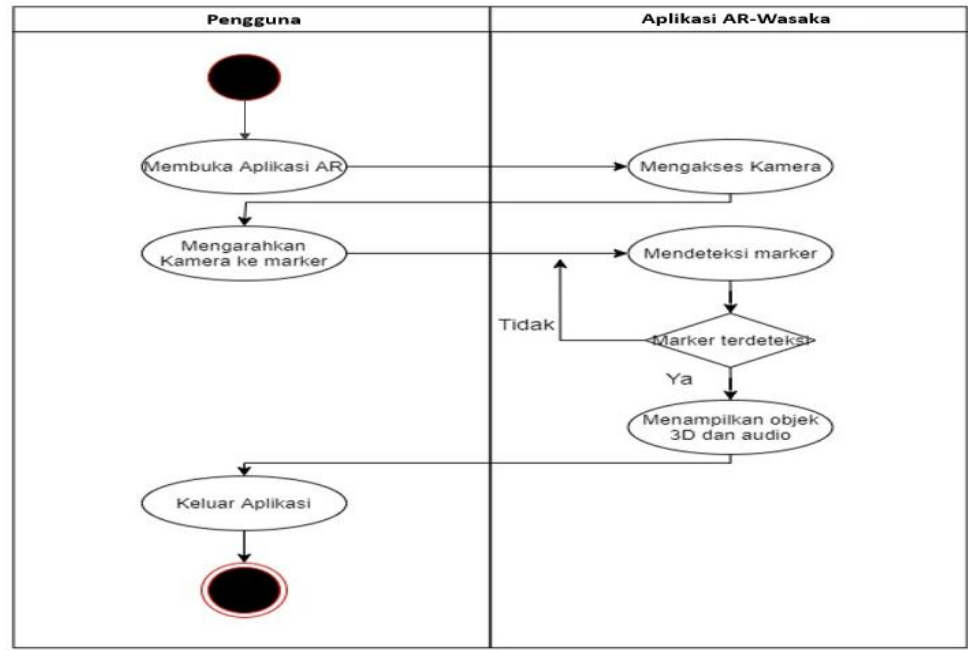

Figure 2. Activity Diagram

In Figure 2, the Activity diagram consists of two swimlanes, namely the user and the AR-Wasaka application. The activity starts from the swimlane where the user opens the AR-Wasaka application and accesses the AR camera, then the application response, namely displaying AR camera access and the user will point the camera at the marker. Furthermore, the application will detect markers, whether the markers are suitable or not. If the markers match, it will generate a 3D object and a description in the form of additional information from the 3D object and audio. If the markers do not match, the application will again detect the pattern from the marker. After the user is presented with the AR-Wasaka application and wants to end the application, the user can opt-out of the application and the activity is complete.

\section{Wireframe}

The wireframe is a framework that has the function of making the layout of an application design, to suit the wishes of the end-user before entering the coding process. Creating a wireframe is one of the important stages in the design process before creating an application, including mobile-based applications. To obtain an application user interface design by the expectations of prospective end-users, the initial design was tested using the A/B Testing method adapted from [11].

Two initial design results that are submitted in the A/B Testing are recommended through an online questionnaire. The most striking design difference is that design A has a portrait display, while design B has a landscape view, furthermore, design A's menu display tends to decrease downward and design B displays the menu widening to the side by adjusting the display ratio of the smartphone screen.

After A/B Testing was carried out using an online questionnaire to 13 respondents consisting of experts in the field of design and potential end-users, the results of the assessment were $32.1 \%$ chose design A and $76.9 \%$ chose design B (See Figure 3). Testing is only done once because the value has exceeded $75 \%$ which refers to research [11] and the final decision is determined that design B (See Figure 4) with the highest value, so that it will be used as a user interface design and proceed to the coding stage.

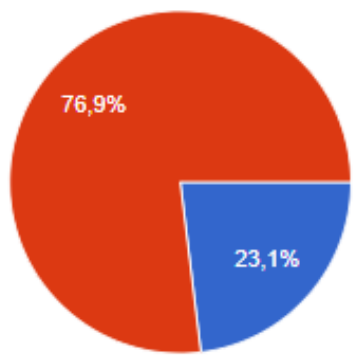

Figure 3. A/B Testing Result Diagram

There are several reasons for respondents who tend to choose design B, including simple appearance, more suitable for landscape viewing positions, tends to be easy to use and learn when using it, and supports user convenience and experience. 


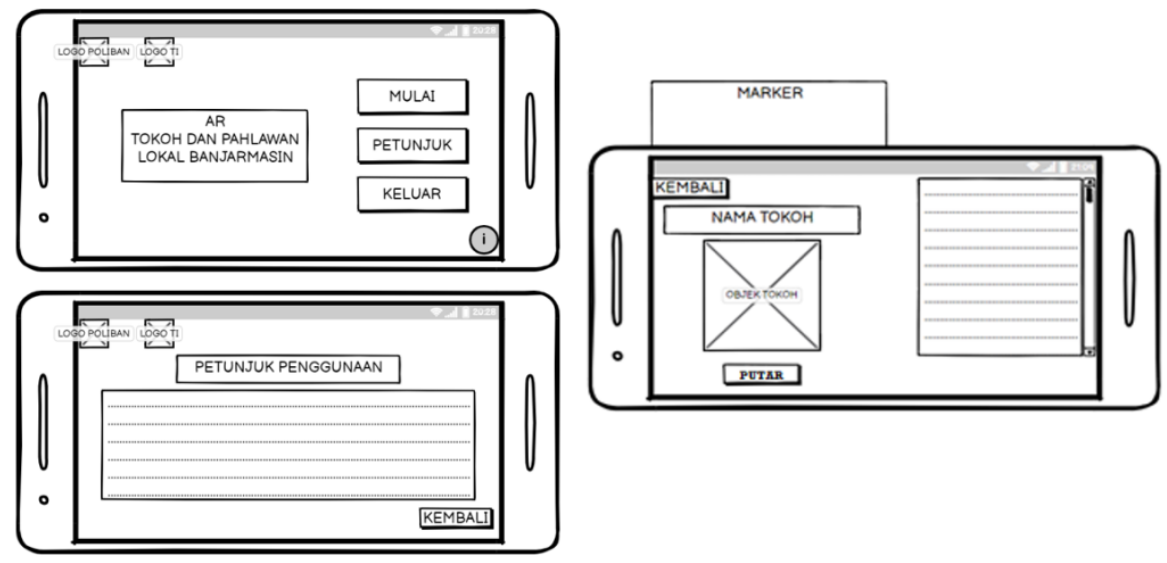

Figure 4. Sample Design B

\subsection{Coding}

To be understood by a machine (in this case a computer), the design must be converted into a form that can be understood by machines using a programming language. The coding stage is the implementation of the design stage so that the creation of an application can be used by end-users. The several sub-stages of coding the AR-Wasaka application are as follows:

\section{Marker Registration}

The marker used is a special barcode beside the photo of the leader/character and hero (See Figure 5). In order for markers to be detected by AR cameras, the markers must first be registered into the Vuforia software as a means of obtaining the results of the patterns to be detected. The reason for using this type of barcode as a marker is because the original photo did not read properly when it was entered into the Vuforia database.

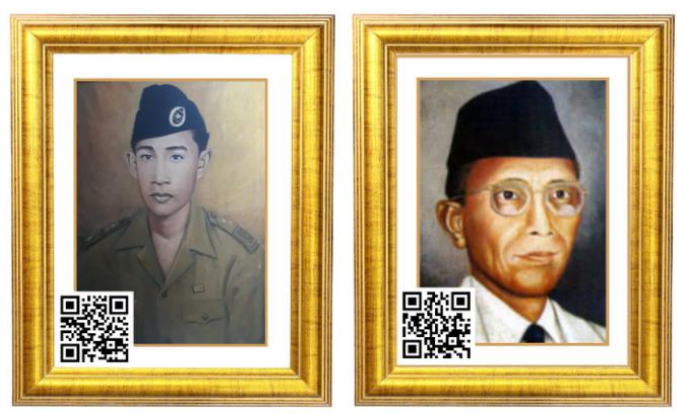

Figure 5. Sample Marker

After the markers have been successfully registered in the Vuforia database, they will further download the database containing the marker patterns which will be integrated when programming the user interface and AR programming.

\section{3D Object Modeling and Creation}

3D object modeling is needed to produce 3D objects as a result of detection from markers and will be generated through AR camera interaction. Blender software is used to create these 3D objects (See Figure $6)$.
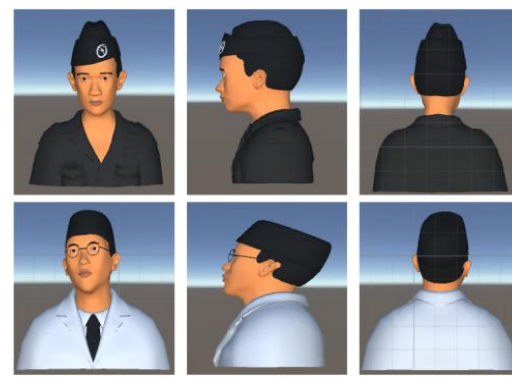

Figure 6. Result of Modeling and Making 3D Objects 
Based on Figure 6, the difficulty faced when making 3D objects is that the geometry modeling stage is the stage of building character models and the background of previously designed sketch models and the texturing stage which is the process of giving certain materials or characteristics to the surface of the object to make it seem more realistic. . Moreover, the 3D objects that will be used in the AR-Wasaka application resemble the original form, art elements and high skills are also needed, especially to shape the face to make it as similar as possible.

\section{User Interface Programming and AR}

Unity 3D software is required for user interface programming (using the $\mathrm{C}$ \# programming language) and AR integration. A database download file for markers is prepared along with the results of 3D object modeling (See Figure 7), the results of the AR-Wasaka application programming that has been built into a file with the apk extension can be seen in Figure 8.

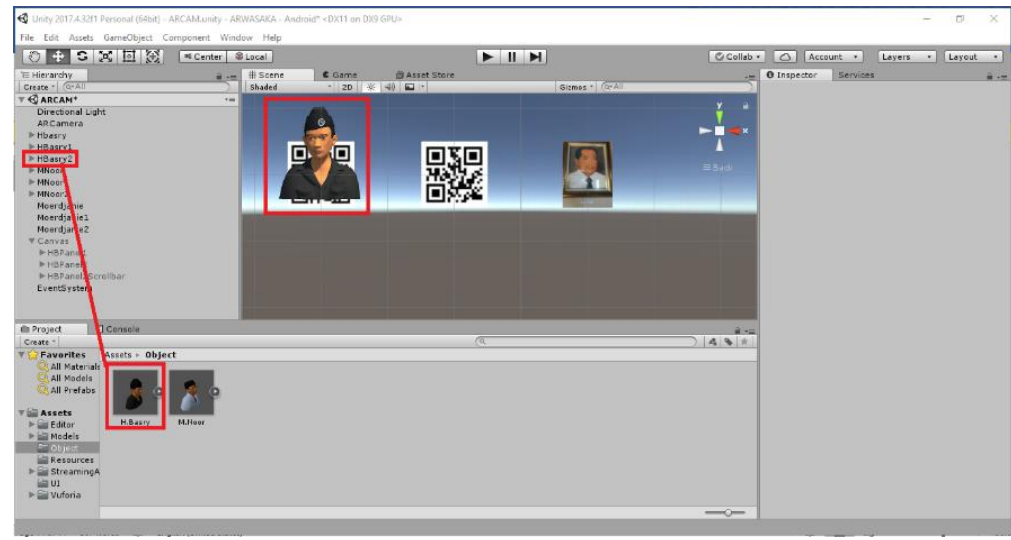

Figure 7. AR-Wasaka Programming Process with Unity 3D Software
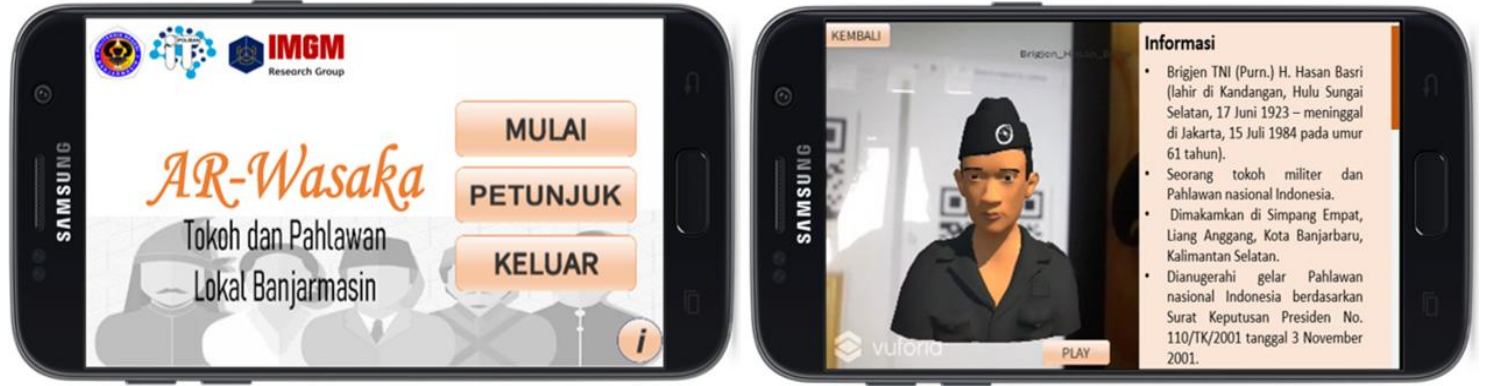

Figure 8. Successfully Run AR-Wasaka Application

Based on Figure 8, this is the result of the AR-Wasaka application that has been running on a smartphone. The user interface has been adjusted based on the proposed design recommendations. As for the interaction of the AR-Wasaka application, which is on the main menu page, the end-user is presented with four buttons. The first button starts which function to go to the AR camera page. Help button to go to the display of the application usage manual page. Exit button to end/exit the application in full. Information button that provides application developer information.

The main interaction on the AR-Wasaka application is on the AR camera page which is accessed via the start button. The AR camera page is used to detect markers that will have an impact on the awakening of 3D object treats magically. There is a play button that functions to bring up audio as if it were a 3D object, such as greeting the end-user and introducing himself, then an information label is provided as a brief description of the object's identity. A back button is also provided to switch to the main menu page.

\subsection{Testing}

In this study, two tests were carried out, namely functionally using black-box testing and nonfunctional using usability evaluation.

\section{Black-Box Testing Results}

To ensure the functioning of the AR-Wasaka application, black-box testing was carried out according to functional requirements (See Table 2), with the results of all test features successfully functioning with a test percentage of $100 \%$ following expectations and it can be agreed that it is suitable for use for end-users and without any problems encountered when running the AR-Wasaka application. 


\section{Usability Evaluation Test Results}

The end users consisted of 11 visitors and 1 guard of the Wasaka Museum Banjarmasin as the main samples of this first phase of testing. After the end-users have finished using the AR-Wasaka application, then they are directed to fill out an online questionnaire from usability evaluation using the System Usability Scale (SUS), a list of statements is presented in Table 4 and the test results are presented in Table 5.

Table 4. List of Statements on the SUS Questionnaire

\begin{tabular}{|c|c|}
\hline Id & Statements \\
\hline Stat1 & $\begin{array}{l}\text { I think I will often use the features in the AR-Wasaka application, especially the AR camera } \\
\text { page access feature. }\end{array}$ \\
\hline Stat2 & $\begin{array}{l}\text { I feel that there are some features in the AR-Wasaka application that are too complicated but can } \\
\text { be made simpler. }\end{array}$ \\
\hline Stat3 & I think the features of the AR-Wasaka app are easy to use. \\
\hline Stat4 & $\begin{array}{l}\text { I think I need help from a technical person to be able to use the features of the AR-Wasaka } \\
\text { application. }\end{array}$ \\
\hline Stat5 & I found that various features are well integrated with the AR-Wasaka application. \\
\hline Stat6 & I think there are many inconsistencies in the features of the AR-Wasaka application. \\
\hline Stat7 & $\begin{array}{l}\text { I think the majority of users will be able to learn about the features of the AR-Wasaka app } \\
\text { quickly. }\end{array}$ \\
\hline Stat8 & I find that there are some features in the AR-Wasaka application that are very impractical to use. \\
\hline Stat9 & I am very confident that I can use the features found in the AR-Wasaka application. \\
\hline Stat10 & $\begin{array}{l}\text { I have to learn many things first before I can use the features found in the AR-Wasaka } \\
\text { application. }\end{array}$ \\
\hline
\end{tabular}

Based on Table 4, there are ten items submitted in the usability evaluation test and the respondents are required to choose them.

Table 5. Usability Evaluation Test Results

\begin{tabular}{|c|c|c|c|c|}
\hline Respondents & Odd Items & Even Items & SUS Score (/100) & Grades \\
\hline 01 & 20 & 14 & 85 & A \\
\hline 02 & 19 & 14 & 82.5 & A \\
\hline 03 & 19 & 17 & 90 & A \\
\hline 04 & 18 & 18 & 90 & A \\
\hline 05 & 20 & 12 & 80 & B \\
\hline 06 & 18 & 18 & 90 & A \\
\hline 07 & 20 & 13 & 82.5 & A \\
\hline 08 & 20 & 16 & 90 & A \\
\hline 09 & 16 & 16 & 80 & B \\
\hline 10 & 18 & 9 & 67.5 & $\mathrm{D}$ \\
\hline 11 & 20 & 8 & 70 & B \\
\hline 12 & 20 & 17 & 92.5 & A \\
\hline \multicolumn{3}{|c|}{ Average SUS Score } & 83.33 & A \\
\hline
\end{tabular}


Based on Table 5, 12 respondents have participated in the usability evaluation test of the ARWasaka application. As many as eight people stated that the AR-Wasaka application has usability which is predicated on Excellent. Then as many as three people stated that the AR-Wasaka application has usability with the predicate Good. Meanwhile, one respondent stated that it was Bad. Respondents who say Excellent and Good tend to look very enthusiastic about using the AR-Wasaka application, they tend to be very happy with the design, features, and interactions that the AR-Wasaka application offers. AR technology can improve user perception and interaction with the real world because AR embraces three characteristics, namely interactive, real-time, and 3D object serving.

To state the final decision, the results obtained are based on the average SUS final score with a value of $83.33 \%$ with the grade letter A with the Excellent predicate, meaning that the AR-Wasaka application as a whole has met the usability aspect and can be recommended for use in the general public who visit the Wasaka Museum in Banjarmasin as well as for users who only want to know the collection, even though they don't visit directly, they can download the application along with the markers. The AR-Wasaka application is available offline and is felt to be very useful and helpful for visitors, especially in this new normal era, so that it makes visitors seem to be traveling virtually with AR interaction treats.

There are some suggestions given by end-users regarding the evaluation of the AR-Wasaka application, namely adding zoom in, zoom out, and rotation buttons on the AR camera page so that the interaction of the $3 \mathrm{D}$ objects that appear can be increased, adding a collection of other objects, provided music, and it is hoped that additional information from the object can be presented in the form of infographic visualization to make it look simpler, but still have good quality information, solid, and contains. These suggestions will be processed into the software increment stage, to be applied as the material for revision of the AR-Wasaka application which aims to continuously improve the performance of the application (application evolution).

\section{CONCLUSION}

AR-Wasaka is an application based on Mobile Augmented Reality and a tool for museums to present their collection objects virtually. In order for the AR-Wasaka application to meet expectations, a user interface design test has been carried out with the result in the form of design B proposed. After the coding process, functionality testing was carried out with the result that all the features of the AR-Wasaka application functioned and met expectations. Furthermore, from the non-functional side with the test results at $83.33 \%$, it is agreed that the AR-Wasaka application has extraordinary usability aspects and can be recommended for further use to the general public.

Future work is to improve the app's features based on end-user suggestions, recommend its continued use to captivate visitors' interest, add other museum collections to serve as AR apps, and further develop it into rich Virtual Reality (VR) technologies with immersive elements.

\section{ACKNOWLEDGEMENTS}

This research is supported by Interactive Media, Game, and Mobile Technologies Research Group. Funding by the Center for Research and Community Service at Politeknik Negeri Banjarmasin.

\section{REFERENCES}

[1] H. Vinoto, H. Nasution, and H. Anra, "Implementasi Markerless Augmented Reality Sebagai Media Informasi Koleksi Museum Berbasis Android (Studi Kasus: Museum Kalimantan Barat)," Jurnal Sistem dan Teknologi Informasi, vol. 4, no. 2, pp. 239-245, August 2016.

[2] I. G. A. Nugraha, I. K. G. D. Putra, and I. M. Sukarsa, "Rancang Bangun Aplikasi Augmented Reality Museum Bali Berbasis Android Studi Kasus Gedung Karangasem dan Gedung Tabanan," Lontar Komputer - Jurnal Ilmiah Teknologi Informasi, vol. 7, no. 2, pp. 93-103, August 2016, doi: https://doi.org/10.24843/LKJITI.2016.v07.i02.p03.

[3] A. S. Laswi and A. Aman, "Implementasi Augmented Reality pada Museum Batara Guru Kompleks Istana Langkanae Luwu," ILKOM - Jurnal Ilmiah, vol. 10, no. 2, pp. 144-151, 2018, doi: https://doi.org/10.33096/ilkom.v10i2.294.144-151.

[4] H. Kato, M. Billinghurst, I. Poupyrev, N. Tetsutani, and K. Tachibana, "Tangible Augmented Reality for Human Computer Interaction," Journal of the Society for Art and Science, vol. 1, issue 2, pp. 97-104, July 2002, doi: https://doi.org/10.3756/artsci.1.97.

[5] H. Kato and M. Billinghurst, "Marker Tracking and HMD Calibration for a Video-based Augmented Reality Conferencing System," In proceeding of the 2nd IEEE and ACM International Workshop on Augmented Reality (IWAR'99), pp. 1-10, February 1999, doi: http://dx.doi.org/10.1109/IWAR.1999.803809.

[6] A. A. Syahidi, H. Tolle, A. A. Supianto, and K. Arai, "BandoAR: Real-Time Text Based Detection System Using Augmented Reality for Media Translator Banjar Language to Indonesian with Smartphone," In proceeding of the 5th IEEE International Conference on Engineering Technologies and Applied Sciences (ICETAS'18), pp. 1-6, November 2018, doi: https://doi.org/10.1109/ICETAS.2018.8629251.

[7] A. A. Syahidi, H. Tolle, A. A. Supianto, and K. Arai, "AR-Child: Analysis, Evaluation, and Effect of Using Augmented Reality as a Learning Media for Preschool Children," In proceeding of the 5th IEEE International 
Conference on Computing Engineering and Design (ICCED'19), pp. 1-6, August 2020, doi: https://doi.org/10.1109/ICCED46541.2019.9161094.

[8] A. A. Syahidi, Subandi, and A. Mohamed, "AUTOC-AR: A Car Design and Specification as a Work Safety Guide Based on Augmented Reality Technology," Journal of Technological and Vocational Education, vol. 26, no. 1, pp. 18-25, May 2020, doi: https://doi.org/10.21831/jptk.v26i1.27907.

[9] Subandi, A. A. Syahidi, Joniriadi, and Mohamed, "Mobile Augmented Reality Application with Multi-Interaction for Learning Solutions on the Topic of Computer Network Devices (Effectiveness, Interface, and Experience Design)," In proceeding of the 3rd IEEE International Conference on Vocational Education and Electrical Engineering (ICVEE'20), pp. 1-6, November 2020, doi: https://doi.org/10.1109/ICVEE50212.2020.9243292.

[10] R. S. Pressman, "Software Engineering A Practitoner's Approach (Seventh Edition)," New York: The McGrawHill Companies Inc., 2010.

[11] A. A. Syahidi, H. Tolle, A. A. Supianto, and T. Hirashima, "Educational Media Design for Learning Basic Programming in Branching Control Structure Material Using Problem-Posing Learning Model," KINETIK: Game Technology, Information System, Computer Network, Computing, Electronics, and Control, vol. 4, no. 4, pp. 325 336, November 2019, doi: https://doi.org/10.22219/kinetik.v4i4.803.

[12] A. A. Syahidi, A. A. Supianto, and H. Tolle, "Design and Implementation of Bekantan Educational Game (BEG) as a Banjar Language Learning Media," International Journal of Interactive Mobile Technologies, vol. 13, no. 03, pp. 108-124, March 2019, doi: http://dx.doi.org/10.3991/ijim.v13i03.9257.

[13] A. A. Syahidi, H. Tolle, A. A. Supianto, and T. Hirashima, "TOLSYASUPI-EduMed: Development of Educational Media Using the Problem-Posing Learning Model for Basic Programming Subjects," Journal of Information Technology and Computer Science, vol. 4, no. 2, pp. 137-155, September 2019, doi: https://doi.org/10.25126/jitecs.201942106.

[14] J. R. Lewis and J. Sauro, "Revisiting the Factor Structure of the System Usability Scale," Journal of Usability Studies, vol. 12, issue 4, pp. 183-192, August 2017. 